\title{
Sowing Dates Effect on Growth and Grain Yield of Some Maize Hybrids
}

\author{
Mahmud A. A. Rahuma
}

\begin{abstract}
A field experiment was carried out at Agricultural Research Station, Faculty of Agriculture, Saba-Basha, Alexandria University, Egypt, during 2017 summer season to study growth and productivity of four maize hybrids (S.C.10, S.C. 168, T.C. 310 and T.C. 352) under four sowing dates (mid April, mid May, mid June and mid July) using split-plot design in three replications. Early sowing (mid April) produced the tallest plants and ears $(242.30 \mathrm{~cm}$ and $25.49 \mathrm{~cm})$, respectively, and largest ear leaf area $\left(880.38 \mathrm{~cm}^{2}\right)$. However, maize sowing in mid May led to increase in ear height $(168.14 \mathrm{~cm})$ and produced the maximum number of rows/ ear (14.62), weight of grains/ ear (200.11 g), 100-kernel weight (33.26 g), shelling percentage $(83.68 \%)$ and grain yield $(3.64 \mathrm{t} / \mathrm{fed}$.$) .$ Conversely, delayed sowing produced the significantly lowest values for all the studied traits. Single crosses, especially, white grains S.C.10 was superior than yellow grains S.C.168 and the three way crosses for all the studied traits. However, white grains T.W.310 showed the highest ear height $(168.76 \mathrm{~cm})$. Single cross 10 sown early (mid April) produced the tallest plants and largest ear leaf area, while sowing it in (mid May) produced the maximum grains weight/ ear, 100-kernel weight, shelling percentage and grain yield (4 t/ fed.). Sowing S.C. 168 in mid May gave the tallest ears $(28.03 \mathrm{~cm})$.
\end{abstract}

Key words: Zea mays, sowing dates, genotypes, growth, yield and its attributes.

\section{INTRODUCTION}

Maize (Zea mays L.) is considered the third most important crop in Egypt and the world because it is used for food, feed and raw materials for some industries. In Egypt, there is a gap between production and consumption of this crop, especially during the last two decades. Field Crops Research Institute, Agricultural Research Center, produced high yielding hybrids (single and three way crosses) suited to summer environmental conditions at different locations under recommended improved cultural practices. Significant differences were detected among maize hybrids in growth, earliness, grain yield and yield attributes (Abo-Shetaia et al., 2000; Hassan, 2000; Griesh and Yakout, 2002; Bruns and Abbas, 2005; Azam et al., 2007; El-Galfy et al., 2009; Gouda et al., 2009; Mirdad et al2010 and Alias et al., 2010).

Regarding sowing date, it is well known that sowing date of maize is dependent on the climatic conditions prevailing in the crop growing area. Several researchers pointed out that the highest values of growth, grain yield and most yield attributes were obtained from May to first half of June plantings as Sharaan et al. (2002), Tarrad et al. (2006), Law-Ogbono and Remison (2009), Beiragi et al. (2011), Koca and Canavar (2014), Franco et al. (2016) and Zhou et al. (2017).

The objective of the present investigation was to study the productivity of four maize hybrids under different sowing dates.

\section{MATERIALS AND METHODS}

A field experiment was conducted at the Experimental Farm, Faculty of Agriculture (SabaBasha), Alexandria University, Egypt, during 2017 summer season to study growth and productivity of four maize hybrids under different sowing dates using split plot design in three replications. The experiment included four sowing dates, i.e., 15/4, 15/5, 15/6 and $15 / 7$ that were randomly arranged in the main plots, while four maize hybrids namely Single crosses (S.C. 10 and S.C. 168) and three way crosses (T.C. 310 and T.C. 352) were allocated in the sub-plots. Each plot consisted of five rows of $3 \mathrm{~m}$ length and $0.7 \mathrm{~m}$ width. At harvest, five guarded plants were randomly chosen to measure plant height $(\mathrm{cm})$, ear height $(\mathrm{cm})$, ear leaf area $\left(\mathrm{cm}^{2}\right)$, ear length $(\mathrm{cm})$, number of rows/ ear, grains weight/ ear (g), 100-kernel weight (g) and shelling percentage, while grain yield $(\mathrm{t} / \mathrm{fed})$ that calculated from the three inner rows after 110 days.

The collected data were statistically analyzed according to Steel and Torrie (1980). Least Significant Difference (L.S.D.0.05) was used to compare the differences between treatment means.

\section{RERSULTS AND DISCUSSION}

\section{Effect of sowing date:}

The studied four monthly dates of sowing, between mid April to mid July, significantly affected all growth characters, grain yield and its attributes (Tables 1 and 2). Results presented in Table (1) revealed that early sowing date (mid April) produced significantly tallest plants $(242.30 \mathrm{~cm})$ and largest ear leaf area $(880.38$ $\mathrm{cm}^{2}$ ), however maize sown in (mid May) showed the highest ears compared with the latest sowing date (mid July). Increasing percentages of the three growth characters over the latest sowings were $(24.55 \%$, $11.60 \%$ and $7.07 \%$ ), respectively.

\footnotetext{
${ }^{1}$ Higher and Moderate Institute of Agricultural Technology , Algeran, Libya

Received April 15, 2018, Accepted May 15, 2018
} 
Similar trend of results was reported by Tarrad et al. (2006) and Rah-Khosravani et al. (2017) for plant height and ear height and Tarrad et al. (2006), Dahmardeh and Dahmardeh (2010), Tismba et al. (2013) and Rah-Khosravani et al. (2017) for ear leaf area.

With respect to sowing dates effect on maize grain yield and its attributes, data presented in Table (2) pointed out that growing maize in the second sowing date (mid May) produced the tallest ears $(26.31 \mathrm{~cm})$, highest number of rows/ ear (14.62), kernels/ ear (200.11), 100-kernel weight (33.26 g), shelling percent $(83.68 \%)$ and grain yield $(3.64 \mathrm{t} / \mathrm{fed}$.). However, the latest sowing date (mid July) showed the lowest values of the abovementioned traits. That might be due to that late sowing decreased the effective rate of grain filling, shortened the effective duration of grain filling and plant growth rate during grain filling was slower because of low daily incident radiation and radiation use efficiency (Cirilo and Andrade, 1995). They, also added that there were no differences in the number of endosperm cells formed among sowing dates, thus the potential capacity of kernels to accumulate assimilates did not contribute to the low final weight observed in later plantings. Similar findings were reported by Mohamed and Shams (1991), Beiragi et al. (2011) and Koca and Canavar (2014) for ear length, Beiragi et al. (2011) for number of rows/ ear, Mohamed and Shams (1991), Beiragi et al. (2011) and Koca and Canavar (2014) for kernels weight per ear, Cirilo and Andrade (1995), Khan et al. (2002), Law-Ogbomo and Remison (2009), Beiragi et al. (2011), Koca and Canavar (2014) and Zhou et al. (2017) for 100-kernel weight, Beiragi et al. (2011) and Koca and Canavar (2014) for shelling percent and Khan et al. (2002), Sharaan et al. (2002), Tarrad et al. (2006), Dahmardeh and Dahmardeh (2010), Casini (2012), Koca and Canavar (2014),

Table 1. Plant height, ear height and ear leaf area means as affected by sowing dates, maize hybrids and their interactions

\begin{tabular}{|c|c|c|c|}
\hline Factor & Plant height (cm) & Ear height $(\mathrm{cm})$ & Ear leaf area $\left(\mathrm{cm}^{2}\right)$ \\
\hline \multicolumn{4}{|l|}{ Sowing date } \\
\hline $15 / 4$ & $242.30^{\mathrm{a}}$ & $160.23^{b}$ & $880.38^{\mathrm{a}}$ \\
\hline $15 / 5$ & $230.92^{b}$ & $168.14^{\mathrm{a}}$ & $869.19^{a b}$ \\
\hline $15 / 6$ & $212.46^{\mathrm{c}}$ & $162.38^{a b}$ & $846.45^{b}$ \\
\hline $15 / 7$ & $194.54^{\mathrm{d}}$ & $150.66^{\mathrm{c}}$ & $822.24^{c}$ \\
\hline L.S.D ${ }_{0.05}$ & 8.62 & 6.17 & 30.17 \\
\hline \multicolumn{4}{|l|}{ Hybrid } \\
\hline S.C. 10 (White grains) & $233.68^{\mathrm{a}}$ & $150.34^{\mathrm{d}}$ & $891.24^{\mathrm{a}}$ \\
\hline S.C. 168 (Yellow grains) & $225.59^{b}$ & $158.21^{\mathrm{c}}$ & $878.58^{a}$ \\
\hline T.C. 310 (White grains) & $210.13^{c}$ & $168.76^{\mathrm{a}}$ & $836.35^{b}$ \\
\hline T.C. 352 (Yellow grains) & $210.81^{\mathrm{c}}$ & $164.10^{b}$ & $812.07^{b}$ \\
\hline L.S.D ${ }_{0.05}$ & 6.21 & 4.60 & 24.37 \\
\hline Sowing date $*$ hybrid & $* *$ & N.S. & $*$ \\
\hline
\end{tabular}

Means followed by the same letter(s) within the same column are insignificantly different at 0.05 level of probability.

$*$ and $* *$ significant at 0.05 and 0.01 probability levels, respectively.
Franco et al. (2016) and Rah-Khosravani et al. (2017) for grain yield.

\section{Effect of genotypes:}

Concerning the differences between maize hybrids for studied growth characters, results in Table (1) demonstrated that, single hybrids, generally, had taller plants, lower ear height and higher ear leaf area than the three way crosses, and there were differences within each group of crosses. Results presented in that table showed that (S.C. 10) had the tallest plants $(233.68 \mathrm{~cm})$, highest ear leaf area $\left(891.24 \mathrm{~cm}^{2}\right)$ and lowest ear height $(150.34 \mathrm{~cm})$ followed by the yellow grains S.C. 168 . Conversely, both three way hybrids had shorter plants, lower ear height and ear leaf area. These results agreed with those reported by Shalaby et al. (1994), Att-Allah (1996), Radwan (1998), Said and Gaber (1999), Mowafy (2003), Mahgoub and EL-Shenawy (2005), Abdel-Maksoud and Sarhan (2008) and EL-Galfy et al. (2009) for plant height, Gouda et al. (1992 and 1998), Radwan (1998), Mahgoub and EL-Shenawy (2005), Abdel-Maksoud and Sarhan (2008) and El-Galfy et al. (2009) for ear height and Gouda et al. (1992 and 1998), Attia (1999), Mowafy (2003), Oraby et al. (2005), Abdel-Maksoud and Sarhan (2008) and Alias et al. (2010) for ear leaf area.

On the other hand, data of grain yield and yield components of the studied maize genotypes are presented in Table (2). Results in that table showed that there were significant differences between the studied single crosses and the three way crosses and within each cross type, where crosses with white grains were significantly higher in grain yield and yield components than those of yellow grains. Abo-Shetaia et al. (2000), Hassan (2000) and Griesh and Yakout (2002) reported the same trend of results. 
Table 2. Means of grain yield and its attributes as affected by sowing dates, maize hybrids and their interactions

\begin{tabular}{|c|c|c|c|c|c|c|c|}
\hline Factor & & $\begin{array}{c}\text { Ear length } \\
(\mathrm{cm})\end{array}$ & $\begin{array}{c}\text { Number of } \\
\text { rows/ ear }\end{array}$ & $\begin{array}{c}\text { Kernels } \\
\text { weight/ ear } \\
\text { (g) }\end{array}$ & $\begin{array}{l}\text { 100-kernel } \\
\text { weight (g) }\end{array}$ & $\begin{array}{c}\text { Shelling } \\
\text { percentage }\end{array}$ & $\begin{array}{c}\text { Grain yield } \\
\text { (t/ fed.) }\end{array}$ \\
\hline \multicolumn{8}{|l|}{ Sowing date } \\
\hline $15 / 4$ & & $25.49^{\mathrm{a}}$ & $14.47^{\mathrm{b}}$ & $194.72^{b}$ & $33.07^{b}$ & $83.26^{b}$ & $3.17^{\mathrm{b}}$ \\
\hline $15 / 5$ & & $26.31^{\mathrm{a}}$ & $14.62^{a}$ & $200.11^{a}$ & $33.26^{\mathrm{a}}$ & $83.68^{a}$ & $3.64^{\mathrm{a}}$ \\
\hline $15 / 6$ & & $25.66^{b}$ & $13.82^{c}$ & $196.64^{b}$ & $31.73^{c}$ & $82.81^{\mathrm{c}}$ & $3.46^{\mathrm{ab}}$ \\
\hline $15 / 7$ & & $22.17^{\mathrm{c}}$ & $12.99^{\mathrm{d}}$ & $164.15^{\mathrm{c}}$ & $29.89^{d}$ & $80.22^{\mathrm{d}}$ & $2.65^{c}$ \\
\hline L.S.D 0.05 & & 0.78 & 0.09 & 2.10 & 0.15 & 0.20 & 0.31 \\
\hline \multicolumn{8}{|l|}{ Hybrid } \\
\hline S.C. 10 & & $25.96^{\mathrm{a}}$ & $15.12^{\mathrm{a}}$ & $200.19^{a}$ & $33.18^{\mathrm{a}}$ & $83.79^{a}$ & $3.68^{a}$ \\
\hline S.C. 168 & & $25.67^{\mathrm{ab}}$ & $14.48^{b}$ & $195.12^{b}$ & $32.82^{b}$ & $83.24^{b}$ & $3.43^{b}$ \\
\hline T.C. 310 & & $25.09^{b}$ & $13.69^{c}$ & $185.92^{c}$ & $31.95^{c}$ & $83.32^{b}$ & $3.01^{\mathrm{c}}$ \\
\hline T.C. 352 & & $22.90^{\mathrm{c}}$ & $12.61^{\mathrm{d}}$ & $174.38^{\mathrm{d}}$ & $29.99^{d}$ & $80.61^{c}$ & $2.78^{\mathrm{d}}$ \\
\hline L.S.D 0.05 & & 0.59 & 0.04 & 1.76 & 0.10 & 0.11 & 0.19 \\
\hline $\begin{array}{l}\text { Sowing date } \\
\text { hybrid }\end{array}$ & $*$ & $*$ & N.S. & $*$ & * & $*$ & $* *$ \\
\hline
\end{tabular}

Means followed by the same letter(s) within the same column are insignificantly different at 0.05 level of probability.

$*$ and $* *$ significant at 0.05 and 0.01 probability levels, respectively.

Table 3. Means of sowing date* hybrid interaction effects on plant height, ear leaf area, ear length, kernels weight/ ear, 100-kernel weight, shelling percentage and grain yield (t/ fed)

\begin{tabular}{|c|c|c|c|c|c|c|c|c|}
\hline $\begin{array}{l}\text { Sowing } \\
\text { date }\end{array}$ & Hybrid & $\begin{array}{c}\text { Plant } \\
\text { height }(\mathbf{c m})\end{array}$ & $\begin{array}{c}\text { Ear leaf } \\
\text { area }\left(\mathrm{cm}^{2}\right)\end{array}$ & $\begin{array}{c}\text { Ear } \\
\text { length } \\
(\mathbf{c m})\end{array}$ & $\begin{array}{c}\text { Kernels } \\
\text { weight/ ear } \\
\text { (g) }\end{array}$ & $\begin{array}{c}100- \\
\text { kernel } \\
\text { weight } \\
(\mathrm{g})\end{array}$ & $\begin{array}{c}\text { Shelling } \\
\text { percentage }\end{array}$ & $\begin{array}{c}\text { Grain yield } \\
\text { (t/ fed.) }\end{array}$ \\
\hline \multirow[t]{4}{*}{$15 / 4$} & S.C. 10 & $254.23^{\mathrm{a}}$ & $946.13^{\mathrm{a}}$ & $26.14^{\mathrm{c}}$ & $210.12^{b}$ & $34.21^{\mathrm{b}}$ & $84.49^{c}$ & $3.89^{\mathrm{ab}}$ \\
\hline & S.C. 168 & $248.30^{\mathrm{ab}}$ & $912.87^{\mathrm{ab}}$ & $26.26^{\mathrm{c}}$ & $200.27^{\mathrm{d}}$ & $34.86^{\mathrm{a}}$ & $83.88^{\mathrm{d}}$ & $3.40^{\mathrm{bc}}$ \\
\hline & T.C. 310 & $238.68^{\mathrm{bc}}$ & $868.92^{\mathrm{c}}$ & $25.30^{\mathrm{d}}$ & $191.96^{\mathrm{e}}$ & $32.69^{\mathrm{e}}$ & $82.79^{f}$ & $3.06^{\mathrm{c}}$ \\
\hline & T.C. 352 & $227.99^{c}$ & $793.60^{\mathrm{e}}$ & $24.26^{\mathrm{e}}$ & $176.53^{\mathrm{f}}$ & $30.52^{\mathrm{kl}}$ & $81.88^{\mathrm{g}}$ & $2.33^{\mathrm{bc}}$ \\
\hline \multirow[t]{4}{*}{$15 / 5$} & S.C. 10 & $241.17^{b}$ & $906.52^{b}$ & $27.60^{\mathrm{ab}}$ & $212.87^{\mathrm{a}}$ & $34.97^{\mathrm{a}}$ & $85.62^{\mathrm{a}}$ & $4.0^{\mathrm{a}}$ \\
\hline & S.C. 168 & $236.26^{b c}$ & $897.36^{\mathrm{bc}}$ & $28.03^{\mathrm{a}}$ & $209.65^{b c}$ & $33.75^{\mathrm{c}}$ & $84.76^{\mathrm{b}}$ & $3.72^{\mathrm{ab}}$ \\
\hline & T.C. 310 & $228.92^{c}$ & $836.47^{\mathrm{cd}}$ & $27.11^{\mathrm{b}}$ & $199.17^{\mathrm{d}}$ & $32.92^{\mathrm{d}}$ & $83.11^{\mathrm{e}}$ & $3.30^{\mathrm{bc}}$ \\
\hline & T.C. 352 & $217.33^{\mathrm{cd}}$ & $836.41^{\mathrm{cd}}$ & $22.50^{f}$ & $178.75^{\mathrm{f}}$ & $31.40^{\mathrm{i}}$ & $81.23^{\mathrm{h}}$ & $3.54^{\mathrm{bc}}$ \\
\hline \multirow[t]{4}{*}{$15 / 6$} & S.C. 10 & $230.16^{\mathrm{bc}}$ & $881.90^{\text {bc }}$ & $26.38^{b c}$ & $207.62^{c}$ & $32.41^{\mathrm{g}}$ & $83.81^{d}$ & $3.64^{b}$ \\
\hline & S.C. 168 & $218.43^{\mathrm{cd}}$ & $867.43^{c}$ & $26.21^{\mathrm{c}}$ & $198.17^{\mathrm{d}}$ & $32.06^{\mathrm{h}}$ & $83.01^{\text {ef }}$ & $3.71^{\mathrm{ab}}$ \\
\hline & T.C. 310 & $192.85^{\mathrm{e}}$ & $819.07^{\mathrm{de}}$ & $25.89^{\mathrm{cd}}$ & $190.74^{\mathrm{e}}$ & $32.11^{\mathrm{h}}$ & $82.74^{f}$ & $3.30^{\mathrm{bc}}$ \\
\hline & T.C. 352 & $208.40^{\mathrm{d}}$ & $817.40^{\mathrm{de}}$ & $24.16^{\mathrm{e}}$ & $190.03^{\mathrm{e}}$ & $30.34^{\mathrm{k}}$ & $81.68^{\mathrm{g}}$ & $3.19^{c}$ \\
\hline \multirow[t]{4}{*}{$15 / 7$} & S.C. 10 & $209.17^{\mathrm{d}}$ & $830.42^{\mathrm{d}}$ & $23.72^{\mathrm{e}}$ & $170.17^{\mathrm{g}}$ & $31.13^{j}$ & $81.26^{\mathrm{h}}$ & $3.20^{c}$ \\
\hline & S.C. 168 & $199.37^{\mathrm{de}}$ & $836.68^{\mathrm{cd}}$ & $22.19^{f}$ & $172.39^{\mathrm{g}}$ & $30.62^{\mathrm{k}}$ & $81.31^{\mathrm{h}}$ & $2.92^{c}$ \\
\hline & T.C. 310 & $180.10^{f}$ & $820.96^{\mathrm{de}}$ & $22.08^{f}$ & $161.83^{\mathrm{h}}$ & $30.09^{\mathrm{m}}$ & $80.65^{\mathrm{i}}$ & $2.41^{\mathrm{d}}$ \\
\hline & T.C. 352 & $189.52^{\mathrm{ef}}$ & $800.90^{\text {de }}$ & $20.69^{g}$ & $152.21^{\mathrm{i}}$ & $27.72^{\mathrm{n}}$ & $77.66^{\mathrm{j}}$ & $2.07^{\mathrm{d}}$ \\
\hline L.S.D. ${ }_{0.05}$ & & 12.10 & 34.22 & 0.83 & 2.28 & 0.20 & 0.24 & 0.36 \\
\hline
\end{tabular}

Means followed by the same letter(s) within the same column are insignificantly different at 0.05 level of probability.

Obtained results revealed that (white grains single cross 10) had the tallest ears $(25.96 \mathrm{~cm})$, highest number of rows/ ear (15.12), shelling percentage $(83.79 \%)$, grain yield (3.68 t/ fed.), heaviest kernels/ ear (200.19 g) and 100-kernel weight (33.18 g). Conversely, yellow grains three way cross 352 showed the lowest values $(22.90$ $\mathrm{cm}, 12.61,80.91 \%, 2.78 \mathrm{t} / \mathrm{fed} ., 174.38 \mathrm{~g}$ and $29.99 \mathrm{~g}$ ) for the above mentioned traits, respectively. The significant genotypic differences were previously detected by several researchers (Shalaby et al., 1994; Gouda et al., 1998; Mowafy, 2003; Azam et al., 2007 and Abdel-Maksoud and Sarhan, 2008).

\section{Interaction effect:}

The data listed in Table (3) present the significant interactions between the two studied factors detected for some growth character, grain yield and yield attributes. 
With respect to growth traits, results indicated that sowing S.C.10 in mid April had the tallest plants $(254.23 \mathrm{~cm})$ and largest ear leaf area $\left(946.13 \mathrm{~cm}^{2}\right)$. However, sowing the same cross in mid May produced the highest kernels weight/ ear (212.87 g), 100-kernel weight $(34.97 \mathrm{~g})$ besides sowing S.C. 168 in mid April $(34.68 \mathrm{~g})$, shelling percentage $(85.62 \%)$ and grain yield (4.0 t/ fed.). However, S.C. 168 produced the tallest ears $(28.03 \mathrm{~cm})$ when it was sown in mid May.

It could be concluded that, late sowing dates (mid June and July) had a negative effect on both single and three way crosses, and that could be attributed to unfavourable climatic conditions, especially air temperature, low daily incident radiation and radiation use efficiency. Also, sowing single crosses, especially white grains, in mid May produced the highest grain yield and yield attributes.

\section{REFERENCES}

Abdel Rasoul, M.A., and G.Kh. Marei. 2016. Potential therapeutic effect of turmeric (Curcuma longa) against adverse effects of penconazole fungicide to white rats. International Journal of Pharmacology and Toxicology. 4 (2) : 178-186.

Abd-Elhady, H.K., G.E. and Abou-Elghar. 2013. Abamectin induced biochemical and histopathological changes in the albino rat, Rattus norvegicus. Journal of Plant Protection Research. 53: 263- 270.

Abdollahi, M., A. Ranjbar., S. Shadnia., S. Nikfar., and A. Rezaie. 2004. Pesticides and oxidative stress: a review Med. Sci. Monitor. 10: 141- 147.

Alhazza, I.M. 2007. Antioxidant and hypo-lipidemic effects of olive oil in normal and diabetic male rats. Saudi Journal of Biological Sciences. 14: 69-74.

Anubama, V.P., H. Honnegowda., K. Jayakumar., G. Krishnappa., K. Narayana., and Y.B. Rajeshwari. 2001. Effect of doramectin on immune response of rats to SRBC antigen. Indian Vet J. 78: 779-782.

Anwar, F., S. Latif., M. Ashraf., and A.H. Gilani. 2007. "Moringa oleifera: a food plant with multiple medicinal uses," Phytotherapy Research. 21( 1): 17-25.

Asiedu-Gyekye, I.J., S. Frimpong-Manso., C. Awortwe., D. A. Antwi., and A. K. Nyarko. 2014. Micro- and Macroelemental Composition and Safety Evaluation of the Nutraceutical Moringa oleifera Leaves. Hindawi Publishing Corporation Journal of Toxicology.Article. ID 786979, $13 \mathrm{p}$.

Barham, D., and P. Trinder. 1972. An improved colour reagent for the determination of blood glucose by the oxidase system.Analyst. 97(151): 142-145.

Chapman, D., R. Castiilla., and J.Campbell. 1959. Evaluation of protein in food determination of protein and food efficiency ratio.Can. J. Biochem. Physil. 37 :676-86.

Eissa, F., and N. Zidan. 2010. Haematological, biochemical and histopathological alterations induced by abamectin and Bacillus thuringiensis in male albino rats. Acta Biol Hung. 61:33-44.

Ellman, G.L., K.D. Courtney., $\quad$ V. Andres., and R.M. Featherstone. 1961. A new and rapid colorimetric determination of acetylcholinesterase activity. Biochem Pharmacol. $7: 88-95$.

El-Shafey, A.M., M.E. Seliem., F. El-Mahrouky., W.M. Gabr., and R.A. Kandil. 2011. Some physiological and biochemical effects of Oshar extract and abamectin biocide on male albino rats. J. Am. Sci. 7 (12): 254-261.

Fakurazi, S., I. Hairuszah., and U. Nanthini. 2008. Moringa oleifera Lam prevents acetamino-phen induced liver injury through restor-ation of glutathione level. Food Chem. Toxicol. 46(8):2611-2615.

Farkaset, J., P. Farkas., and D. Hyde. 2004. Liver and gastroenterology tests, ini basic skills in interpreting laboratory data.Mary Lee 3rd Edition. American Society of Health System Pharmacists, Bethesda, Maryland. USA 330-336.

Faye, B., B. Bucheton., and A.L. Banuls. 2011. Prevalence of Leishmaniainfantum in a rural area of Senegal: analysis of risk factors involved in transmission to humans. J Trans R. Sco Trop Med Hyg. 105: 333 - 340.

Fournier, D., and A. Mutero. 1994. Modification of acetylcholinesterase as a mechanism of resistance to insecticides, Comp Biochem Physiol. 108C: 19-31.

Gonzalez, A., A. Sahagun., M.J. Diez., N. Fernandez., M. Sierra., and J.J. Garcia. 2009. The pharmacokinetics and metabolism of ivermectin in domestic animal species. The Veterinary Journal. 179:25-37.

Gornall, A.C., C.J. Bardawill., M.M. David., 1949. Determination of serum protein by means of biuret reaction. J. Biol. Chem. 177: 751-756.

Hsu, D.Z., C.H. Hsu., B.M. Huang., and M.Y. Liu. 2001. Abamectin effects on aspartate aminotransferase and nitric oxide in rats. Toxicology. 165:189-193

Huang, G.J., J.S. Deng., and S.S. Huang. 2012. Protective effect of androstenol from Antrodiacamphorata submerged whole broth against carbon tetrachloride-induced acute liver injury in mice. Food Chem. 132:709-16.

Khalafalla, M.M., E. Abdellatef., H.M. Dafalla., A.A. Nassrallah., K.M. Aboul-Enein., D.A. Lightfoot., F.E. ElDeeb., and H.A. El-Shemy. 2010. Active principle from Moringa oleifera Lam leaves effective against two leukemias and a hepatocarcinoma. Afr. J. Biotechnol. 9:8467-8471.

Khaldoun-Oularbi, H., C. Richeval., N. Djenas., M. Lhermitte., L. Humbert., and A. Baz. 2013. Effect of subacute exposure to, abamectin (insecticide) on liver rats (Rattus norvegicus). Ann Toxicol Anal. 25:63-70

Kolar, L., N.K. Erzen., L. Hogerwerf., and C.A. Van Gestel. 2008. Toxicity of abamectin and doramectin to soil invertebrates. Environ Pollut. 151:182-189. 
Kose, L.P., I. Gülçin., H. ? zdemir., A. Atasever., S.H. Alwasel., and C.T. Supuran. 2016. The effects of some avermectins on bovine carbonic anhydrase enzyme.Journal of enzyme inhibition and medicinal chemistry. 31(5):773-778.

Lee, D.K., H. Kim., and Y.S. Cha. 2015. Methaemoglobinaemia in acute indoxacarb poisoning. Emerg Med Australas. 27:376-377.

Mirdad, Z.M. 2010.Influence of cultivars, plant spacings, and mineral NPK fertilizers application on vegetative growth, yield and its components and kernels quality of sweet corn. Alex.Sci.Exch.J.31:79-94

Mudaraddi, T.Y., R.R. Potadar., and B.B. Kaliwal. 2012. Indoxacarb induces liver oxidative stress in Swiss Albino Mice. European Journal of Experimental Biology. 2:180186

Nassar, AM. 2015. Acetylcholine esterase: A Universal toxicity biomarker. J.Agric.\&-Env.Sci.Dam.Univ.,Egypt. Vol.14 (1): 1-14.

National Research Council, 2011. Guide for the Care and Use of Laboratory Animals, 8th ed.; the National Academies Press: Washington, DC, USA.

Ndong, M., M.S. Uehara., I. Katsumata., and K. Suzuki. 2007. "Effects of oral administration of Moringa oleifera Lam on glucose tolerance in Goto-Kakizaki and wistar rats," Journal of Clinical Biochemistry and Nutrition. 40(3):229233.

Ola-Davies, O.E., S.G. Olukole., and O.A. Amoo. 2014. Haematological and serum biochemical variables in rats treated with ethanol extract of the root of Moringa oleifera. African J Biomed Res. 17:31-35

Osman, H.H., M.M. Ahmed., B. Osman., and A.M. Elhassan. 2015. Assessment of acute toxicity and LD 50 of Moringa oleifera ethanolic leave extract in albino rats and rabbits. J Med BiolSci Res. 1:38-43

Oyewole, O.I., and B.F. Olabiyi. 2014. Ameliorating Effect of Moringa oleifera Leaf Extract on Chlorpyrifos-Induced Toxicity in the Brain of Wistar Rats. Am J Biochem. 4:9397.

Park, J. S., H. Kim., S.W. Lee., and J.H. Min. 2011. Clin.Toxicol, 49: 744-746

Pohanka, M. 2014. Inhibitors ofacetylcholin-esterase and butyrylcholin-esterase meet immunity. Int. J. Mol. Sci. 15: 9809-9825.

Rasika, C. T., M. L. Sangita., and B.J. Ravindra., 2011. Evaluation of phenol and flavonoid content from aerial parts of Tecomastans.International Journal of Pharmacy and Pharmaceutical Science. 3(4).

Re, R., N. Pellegrini., A. Proteggente., A. Pannala., M. Yang., and C. Rice-Evans. 1999. Antioxidant activity applying an improved ABTS radical cationdecolorization assay. Free RadicBiolMed. 26: 1231-1237.

Reitman, S., and S.A. Frankel. 1957. Colorimetric method for the deter-mination of serum glutamic oxalacetic and glutamic pyruvic trans-aminases. Am. J. Clin. Pathol. 28: 56-63.
Sakr, S.A. 2007. "Ameliorative Effect of Ginger (Zingiber officinale) on Mancozeb Fungicide Induced Liver Injury in Albino Rats." Australian Journal of Basic and Applied Sciences. 1: 650656.

Sandeep, K., C. S. Mukhopadhyay., J. S. Arora., and R.S. Sethi. 2016. Indoxacarb interaction alters immunotoxic and genotoxic potential of endotoxin. J. Pestic. Sci. 41(3):65-70.

Sharma, N., P.C. Gupta., and C.V. Rao. 2012. Nutrient content, mineral, content and antioxidant activity of Amaranthusviridis and Moringaoleifera leaves. Res. J. Med. Plant. 6(3):253-259.

Shit, S.P., R.S. Panghal., V. Kumar., and R.D. Rana. 2008. Acute toxicity and gross behavioural effects of indoxacarb in laboratory animals. Haryana Vet. 47: 49-51.

Singh, D., P.V. Arya., V.P. Aggarwal., and R..S. Gupta. 2014. Evaluation of Antioxidant and Hepatoprotective Activities of MoringaoleiferaLam. Leaves in Carbon TetrachlorideIntoxicated Rats. Antioxidants. 3: 569-591.

Subadra, S., J. Monica., and D. Dhabhai. 1997. Retention and storage stability of beta-carotene in dehydrated $\mathrm{M}$. oleifera. Inter J Food Science and Nutri, 48:373 - 379.

Tietz, N.W. 1995. Clinical Guide to laboratory Tests. 3rd ed. Phila-delphia: WB Saunders,pp: 268-273.

Tomlin, C.D.S. (Ed.) 2004. A world compendium.The ePesticide Manual. Thirteen's Edition. Version 3.0 200304. British Crop Protection Council (BCPC).

Tomlin, C.D.S. 2005. The e-pesticide manual: a world compendium, Thirteen's Edition. British Crop Production Council, London

Verma, A.R. M. Vijayakumar., C.S. Mathela., and C.V. Rao. 2009. In vitro and in vivo antioxidant properties of different fractions of Moringa oleifera leaves; Food and Chemical Toxicology. 47: 2196-2201.

Von Stein, R.T., K.S. Silver., and D.M. Soderlund. 2013. Indoxacarb, metaflumi-zone, and other sodium channel inhibitor insecticides: Mechanism and site of action on mammalian voltage-gated sodium channels. Pestic Biochem Physiol. 106:101-112.

Vongsak, B., P. Sithisarn., W. Gritsanapan., 2012. "HPLC quantitative analysis of three major antioxidative components of Moringa oleifera leaf extracts," Planta Medica. 78(11): 1252 .

Wallace, A.H. 2007. Principles and Methods of Toxicology. Healthcare USA, Inc., New York, 5th ed. 369-453.

Walmsley, R.N., and G.H. White. 1994. A Guide to Diagnostic Clinical Chemistry. 3rd ed., Blackwell Publication, London, UK. 543 pp.

Whitfield, J.B., D.W. Moss., G. Neale., M. Orme., and A. Breckenridge. 1973. Changes in plasma -glutamyltranspeptidase activity associated with alterations in drug metabolism in man. Br Med J. 10;1(5849) :316-318.

Wing, K.D., M.E. Schnee., M. Sacher., and M. Connair. 1998. Anoveloxadiazine insecticide is bioactivated in lepidopteran larvae. Archive Insect Biochem.Physiol.37:91-103. 
Yang, Y.S., T.H. Ahn., J.C. Lee., C.J. Moon., S.H. Kim., W. Jun., S.C. Park., H.C. Kim., and J.C. Kim. 2008. Protective effects of Pycnogenol on carbon tetrachlorideinduced hepatotoxicity in Sprague-Dawleyrats.Food Chem. Toxicol. 46:380-387.

Young, D.S., L.C. Pestaner., and V. Gibberman. 1975. Effect of drug on clinical laboratory tests. Clinl. Chem. 21: D431-2.
Yousef, M.I., T. AwadI., and E.H.Mohamed. 2006. Deltamethrin-induced oxidative damage and biochemical alterations in rat and its attenua-tion by Vitamin E. Toxicology. 227(3):240-247.

Zanoli, J., M. Maioli., H. Medeiros., and F. Mingatto. 2012. Abamectin affects the bioenergetics of liver mitochondria: A potential mechanism of hepatotoxicity. Toxicol Vitr. 26:51-56.

\section{الملخص العربي}

\section{تأثثر مواعيد الزراعة على نمو ومحصول الحبوب لبعض هجن الأرة الثامية}

$$
\text { محمود أبو عجيلة على رحومة لمدول }
$$

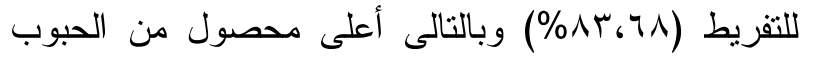
(ع T، طن/ فدان)- وعلى العكس من ذلك نجد أن تأخير زر اعة الذرة الثامية إلى منتصف يوليو أدى إلى نقص من معنوى فى جميع الصفات التى تم در استها. من جهة أخرى فقد تفوقت الهجن الفردية خاصة الهجين الفردى (·) (1)

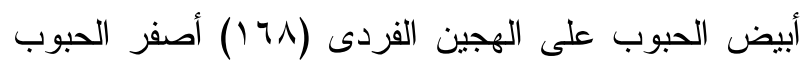
و الهجن الثلاثية بيضاء أو صفر اء الحبوب التى تم دراستها فى جميع الصفات التى تم قياسها، عدا الهجين الثلاثى

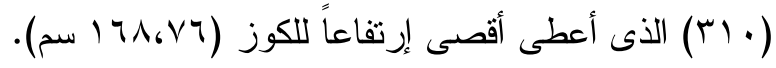
كذلك أوضحت النتائج أن زراعة الهجين الفردى (·)

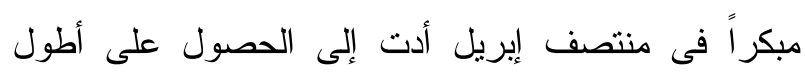

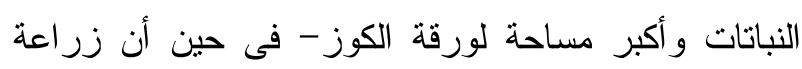

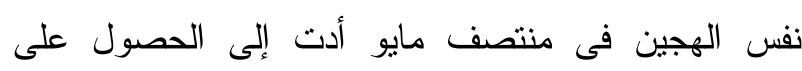

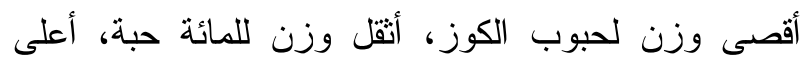
نسبة للتفريط وكذلك أعلى محصول من الحبوب (ع طن/

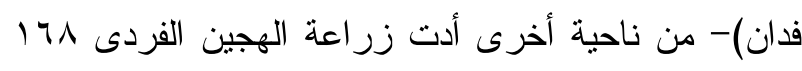

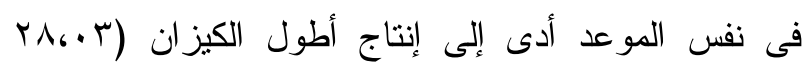
سم).
نفذت تجربة حقلية بمزرعة كلية الزر اعة- سابا باثاجامعة الإسكندرية خلا الموسم الصيفى لعام IV Y.IV

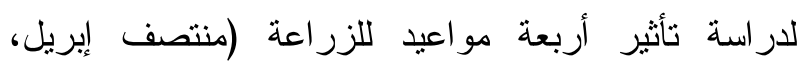

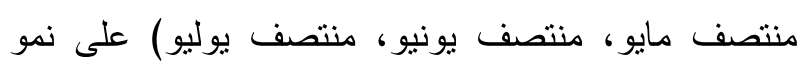

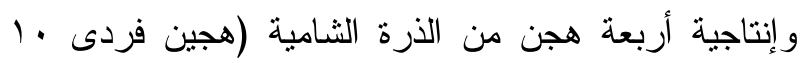

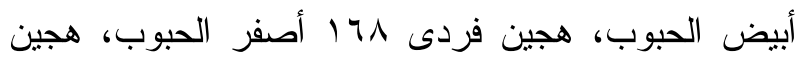

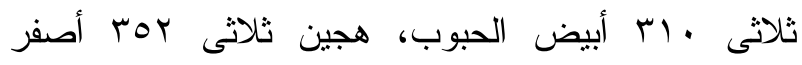

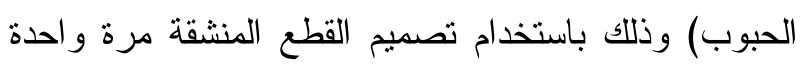

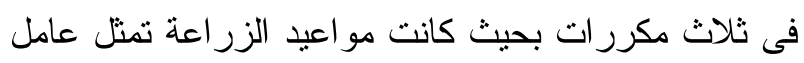

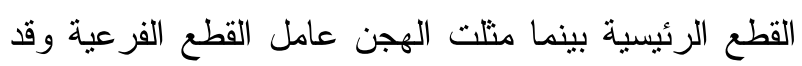
أوضحت النتائج أن الزراعة المبكرة (منتصف إبريل) أدت التهي

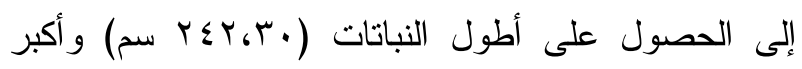

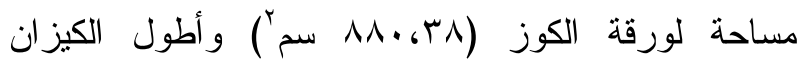

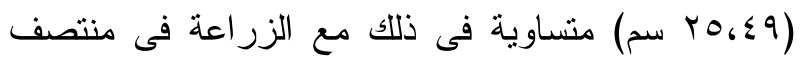

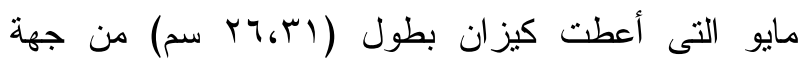

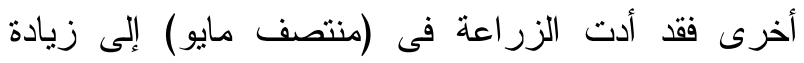

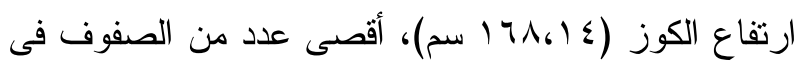

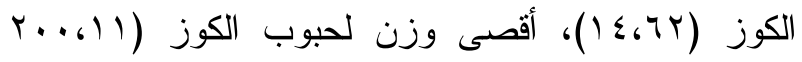

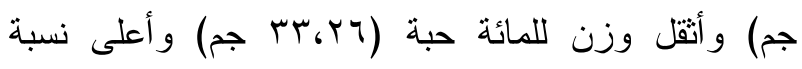

